\title{
The Use Of E-Muamalat Facilities In Attracting Customer Interest IN PT. Bank Muamalat Indonesia TBK. KCP Panyabungan
}

\author{
Misbah $^{1}$, Budi Gautama Siregar ${ }^{2}$, Muhammad Wandisyah R Hutagalung ${ }^{3}$, Samsudidn \\ Muhammad $^{4}$ \\ ${ }^{1}$ IAIN Padangsidimpuan (Perbankan Syariah, FEBI, IAIN Padangsidimpuan) \\ ${ }^{2}$ IAIN Padangsidimpuan (Perbankan Syariah, FEBI, IAIN Padangsidimpuan) \\ ${ }^{3}$ IAIN Padangsidimpuan (Perbankan Syariah, FEBI, IAIN Padangsidimpuan) \\ ${ }^{4}$ IAIN Padangsidimpuan (Ekonomi Syariah, FEBI, IAIN Padangsidimpuan) \\ misbah@gmail.com ${ }^{1}$, budigautama@iain-padangsidimpuan.ac.id ${ }^{2}$, wandisyah@iain-padangsidimpuan.ac.id \\ , samsuddin@iain-padangsidimpuan.ac.id ${ }^{4}$
}

\begin{abstract}
ABSTRAK
Fasilitas jasa perbankan dengan menggunakan teknologi informasi disebut dengan Elektronik Muamalat. Dengan adanya kemajuan di bidang teknologi informasi ini nasabah dapat melakukan transaksi darimana dan kapan saja dengan cepat dan mudah, sehingga dapat lebih meningkatkan volume transaksi yang terjadi pada suatu bank tersebut. Namun hanya sebagian orang nasabah Bank Muamalat Indonesia Tbk. KCP Panyabungan yang menggunakan E-Muamalat.Tujuan penelitian ini adalah untuk menegetahui bagaimana persepsi nasabah terhadap E-Muamalat dan faktor yang menyebabkan nasabah menggunakan E-Muamalat pada PT. Bank Muamalat Indonesia Tbk. KCP Panyabungan. Teori yang digunakan dalam penelitian ini antara lain:Pengetian Minat, Jasa Perbankan, Jasa Perbankan Teknologi, Elektronik Banking, Sejarah Banking, Jenis Transaksi Elektronik dan Produk-Produk pada PT. Bank Muamalat Indonesia Tbk. KCP Panyabungan. Penelitian ini adalah penelitian lapangan dengan menggunakan pendekatan kualitatif dengan teknik pengumpulan data menggunakan metode Wawancara, Dokumentasi, Observasi, sedangkan sumber data yang digunakan berupa primer dan sekunder. Berdasarkan hasil penelitian yang telah dilakukan oleh peneliti dapat diketahui persepsi nasabah terhadap E-Muamalat sangat praktis, super cepat dan akurat tanpa harus datang ke kantor ketika hendak bertransaksi, selain itu faktor penyebab nasabah menggunakan E-Muamalat karena tidak mau ketinggalan terhadap produk perbankan berbasis Elektronik Banking.

Kata Kunci: Minat, Fasilitas dan E-muamalat
\end{abstract}

ABSTRACT

Banking service facilities using information technology are called Electronic Muamalat. With advances in information technology, customers can make transactions from anywhere and anytime quickly and easily, so as to further increase the volume of transactions that occur at a bank. However, only some of the customers of Bank Muamalat Indonesia Tbk. KCP. Panyabungan that uses E-Muamalat. The purpose of this study is to find out how customers perceive E-Muamalat and the factors that cause customers to use E-Muamalat at PT. Bank Muamalat Indonesia Tbk. KCP Panyabungan. Theories used in this study include: Definition of Interests, Banking Services, Technology Banking Services, Electronic Banking, Banking History, Types of Electronic Transactions and Products at PT. Bank Muamalat Indonesia Tbk. 
Panyabungan KCP. This research is a field research using a qualitative approach with data collection techniques using the Interview, Documentation, Observation method, while the data sources used are primary and secondary. Based on the results of research that has been carried out by researchers, it can be seen that customer perceptions of E-Muamalat are very practical, super fast and accurate without having to come to the office when they want to transact, besides that the factors that cause customers to use E-Muamalat because they don't want to miss out on electronic-based banking products. Banking.

Keywords: Interests, Facilities and E-muamalat

\section{A. PENDAHULUAN}

Bank syariah di Indonesia lahir sejak tahun 1992. Bank syariah pertama di indonesia adalah PT. Bank Muamalat Indonesia Tbk. Pada tahun 1992 hingga 1999, Perkembangan PT. Bank Muamalat Indonesia Tbk, masih tergolong stagnan, namun sejak terjadi krisis moneter yang berdampak buruk pada beberapa bank konvensional, membuat para bankir mulai berpikir dan mencari alternatif perbankan dengan sistem syariah. Hal ini dikarenakan PT. Bank Muamalat Indonesia Tbk tidak terlalu terkena dampak dari krisis moneter.(Ismail, 2011:24)

Bank adalah salah satu lembaga keuangan yang beroperasi tidak ubahnya sama seperti perusahaan lainnya, yaitu tujuannya mencari keuntungan. Dalam perjalanan perbankan saat ini, bank sudah berkembang dan dapat dibagi menjadi 2 golongan besar, yaitu bank konvensional dan bank syariah. Keberadaan bank harus bermanfaat dan harus dapat dirasakan langsung oleh siapa saja baik oleh deposan maupun debitur, pelaku bisnis, karyawan. (Maryanto Supriyono, 2011:1)

Bagi pelaku Bisnis atau pengusaha, bank merupakan media perputaran lalu lintas uang. Semakin sempurna produk dan jasa yang diberikan bank kepada nasabahnya, tentunya akan memperlancar kegiatan bisnis nasabah serta lebih mudah untuk bertransaksi di bank tersebut. Hal ini tidak terlepas juga dari kemampuan bank menyediakan sumber daya manusia yang handal, yang memperlengkapi dengan sistem teknologi informasi.(Maryanto Supriyono, 2011:3)

Nasabah merupakan nafas kehidupan bagi bank agar mampu manjalankan setiap kegiatannya. Setiap bank dituntut untuk memberikan pelayanan yang baik dan berkualitas. Dengan berbagai layanan menarik dari berbagai bank, maka masyarakat akan lebih selektif dalam memilih lembaga keuangan yang menurut mereka adalah terbaik,peran karyawan atau seorang pelayan dalam dunia perbankan sangat penting seiring dengan meningkatnya persaingan bisnis di dunia perbankan.(Maryanto Supriyono, 2011:26)

Dunia perbankan menyadari betapa pentingnya memperoleh dan mempertahankan kepercayaan nasabah bagi keberhasilan bisnis bank. Perbankan berlomba-lomba menunjukkan sikap lebih menghargai nasabah dan mengembangkan fasilitas yang ada. Dengan memberikan pelayanan yang terbaik , maka pastinya akan lebih banyak masyarakat 
Misbah ${ }^{1}$, Budi Gautama Siregar ${ }^{2}$, Muhammad Wandisyah $R^{3}$, Samsuddin Muhammad ${ }^{4}$

yang berminat menggunakan jasa perbankan tersebut.

Minat merupakan kesadaran diri dari seseorang terhadap objek, orang, masalah, atau situasi yang memiliki berkaitan dengan dirinya. Artinya minat harus dilihat sebagai suatu kesadaran. Oleh karena itu minat adalah suatu aspek psikologis seseorang untuk menaruh perhatian yang tinggi pada kegiatan tertentu dan mendorongnya untuk melakukan. Minat yang sering diekspresikan dalam suatu kegiatan akan semakin kuat, sedangkan apabila tidak tersalurkan maka akan lemah. Untuk itu minat menjadi suatu penyabab terjadinya suatu kegiatan dan hasil yang nantinya akan diperoleh. (Muhibbin Syah, 2003:150)

Perkembagan dunia perbankan pada saat ini sangatlah pesat. Banyaknya pesaing yang dapat menyebabkan perusahaan sulit untuk mempertahankan nasabah. Dalam usaha untuk memenangkan usaha tersebut, maka pemanfaatan teknologi merupakan hal yang wajib dilakukan oleh lembaga perbankan. Peranan teknologi dalam membangun dan penyediaan produk baru atau fasilitas jasa perbankan. Para pengguna jasa perbankan dimanjakan dengan berbagai fasilitas yang memudahkan mereka untuk melakukan transaksi perbankan.(Edhy Sutanta, 2017:59)

Fasilitas berdasarkan (Kamus Bahasa Indonesia,) adalah sesuatu yang dapat membantu memudahkan pekerjaan, tugas dan sebagainya. Sehingga dapat disimpulkan bahwa fasilitas adalah segala sesuatu yang dapat membantu

POINT Vol. 2, No. 2, Des 2021

pemanfaatannya.(Nasrul Makdis, 2020:45) Untuk mengantisipasi persaingan maka Bank Muamalat Indonesia dengan berupaya untuk mengembangkan teknologi muamalat berupa Internet Bangking, Phone Banking, Mobile Banking dan ATM (Automotic Teller Machine).

Internet Banking, Merupakan fasilitas khusus yang diberikan oleh bank kepada nasabah untuk dapat memeriksa saldo, melaksanakan proses transfer, melaksanakan pembayaran tagihan dan pembelian melalui sarana internet.

Phone Banking merupakan fasilitas khusus dimana nasabah bisa memeriksa saldo dana, melakukan transfer dan pembayaran melalui sarana telepon.

Mobile Banking, merupakan fasilitas dimana nasabah melakukan berbagai transaksi melaui smart-phonenya. bentuknya aplikasi mobile banking yang tersedia berbasis aple, android dan blackberry. ATM, Merupakan fasilitas dimana nasabah bisa menarik dana tabungan atau gironya dengan kartu ATM melalui jaringan ATM. (Ikatan Bankir Indonesia, 2014:177)

Masyarakat dalam bahasa Inggris disebut dengan istilah "Social Group" artinya himpunan atau kesatuan-kesatuan manusia yang hidup oleh karena adanya hubungan antara mereka. (Sarjono Soekanto, 2002:166) Masyarakat sebagian besar berinteraksi antara individuindividu yang berda di dalam kelompok. 
Masyarkat memiliki peranan yang penting dalam dunia ekonomi atau perbankan.

Layanan yang diberikan bank mempunyai nilai bagi nasabah jika dilihat dari banyak manfaat yang diberikan bank untuk memenuhi kebutuhan yang diminta para nasabah. Manfaat yang dimaksud ketika suatu sistem yang disediakan banyak digunakan dan dapat dipahami secara mudah atas produk yang ditawarkan. Misal pada fitur yang disediakan ebanking pada aplikasi yang akan di buka maka tidak semua nasabah mengerti atau mau menggunakan layanan yang di sediakan. Hal ini bisa menimbulkan kemubadziran atas kelebihan fitur. Selain itu jika semakin banyak tampilan yang tidak di perlukan nasabah akan akan semakin membuat kesulitan bagi nasabah yang menggunakan.

Pada dasarnya hal ini yang mendorong peneliti untuk melakukan penelitian terhadap masyarakat Panyabungan, untuk melihat pengetahuan nasabah dalam menggunakan emuamalat. Dari observasi awal dengan sistem wawancara pada tanggal 12 November 2020 dengan ibu Hamidah Nasution sebagai Relationship Manager di Bank Muamalat KCP Panyabungan", hanya sebagian orang nasabah bank Muamalat yang menggunakan fasilitas emuamalat karena faktor minimnya pengetahuan nasabah yang berhubungan dengan elektronik seperti: yang harus menggunakan Android dan yang lainnya. Sehingga mereka rela harus datang mengantri ke kantor bank untuk bertransaksi"

\section{B. Tinjauan Teoritik}

1. Pengertian Minat

Minat sebagai aspek kejiwaan bukan hanya mewarnai perilaku seseoang untuk melakukan aktifitas yang menyebabkan seseorang merasa tertarik kepada sesuatu. Secara sederhana minat (interest) berarti kecenderungan atau kegairahan yang tinggi atau keinginan yang besar terhadap sesuatu.(Muhibbin Syah, 2003:151)

Minat merupakan suatu kecenderungan untuk memberikan perhatian dan bertindak terhadap orang, aktivitas atau situasi yang menjadi objek dari minat tersebut dengan disertai perasaan senang. Minat adalah kemauan hati seseorang untuk memiliki atau menggunakan suatu objek yang menyangkut dirinya dengan disertai perasaan senang tanpa ada paksaan dari orang lain. Faktor-faktor yang mempemgaruhi minat diantaranya; persepsi, keyakinan, dan sikap(Damri Batubara, dkk., 2020:46)

Minat merupakan suatu keadaan atau kondisi dimana ketika seseorang telah mempunyai rasa ketertarikan pada hal tertentu yang diikuti dengan keinginan untuk belajar atau mempelajarinya, membuktikan serta mengetahui lebih dalam lagi akan suatu hal disebut. Pengertian minat yang lain yaitu perasaan, harapan, pendirian, kecenderungan serta prasangka yang bercampur dan terkumpul menjadi satu kesatuan yang bisa memberikan arah kepada individu pada suatu pilihan dan atau keputusan. 
Misbah ${ }^{1}$, Budi Gautama Siregar ${ }^{2}$, Muhammad Wandisyah $\mathbf{R}^{3}$, Samsuddin Muhammad

Faktor-faktor yang memengaruhi minat ada dua yaitu:

1. Faktor dari dalam (internal)

Faktor dari dalam (internal) yang berarti bahwa sesuatu perbuatan memang diinginkan karena seseorang senang melakukannya. Di sini minat datang dari diri orang itu sendiri. Di dalam penelitian ini yang merupakan faktor intrinsik adalah agama dan psikologis.

2. Faktor dari luar (eksternal)

Faktor dari luar (eksternal) dimana berarti sesuatu perbuatan dilakukan atas dasar dorongan atau pelaksanaan dari luar. Orang melakukan kegiatan ini karena didorong atau dipaksa dari pihak luar. Seperti keluarga, teman, dan metode atau cara pembelajaran(Rodame Monitorir Napitupulu, dkk., 2021:43)

Jadi minat merupakan dorongan atau keinginan dalam diri seseorang terhadap suatu objek, yang dapat memepengaruhinya untuk memilih dan menggunakan objek tersebut berdasarkan keputusan yang dipilihnya.

Minat nasabah adalah sumber motivasi bagi nasabah yang dapat mendorong untuk melakukan kegiatan transaksi terhadap bank ketika ia bebas memilih.(Muhibbin Syah, 2003:154) Ketika seseorang menilai bahwa suatu objek bisa bermanfaat baginya, maka ia bisa berminat terhadap hal tersebut, yang kemudian bisa mendatangkan kepuasan. Jasa Perbankan
POINT Vol. 2, No. 2, Des 2021

Selain menjalankan fungsinya sebagai intermdiary (penghubung) anatara pihak bank yang membutuhkan dana (deficit unit) dengan pihak kelebihan dana bank dapat pula melakukan berbagai pelayanan jasa perbankan.(Bustari dan kurnia, 2016:56)

Jasa perbankan adalah kegiatan dapat di defenisikan secara tersendiri, pada hakikatnya bersifat tidak teraba, untuk memenuhi kebutuhan dan tidak harus terikat pada penjualan produk atau jasa lainnya. Semua aktivitas yang dilakukan bank secara langsung terkait tugas dan fungsinya sebagai lembaga intermediasi, atau kegiatan pelayanan yang diberikan kepada nasabahnyaselain aktifitas pengumpulan dana. Semakin lengkap jasa-jasa perbankan yang diberikan tentunya akan semakin sehingga demikian dapat menarik minat nasabah untuk menyerahkan semua keperluan aktifitas pada bank tersebut.(Bustari dan kurnia, 2016:53)

Jasa Perbankan Berbasis Teknologi

Teknologi e-muamalat adalah fasilitas yang digunakan sebagai transaksi. Dalam upaya meningkatkan efisiensi kegiatan operasional dan mutu layanan kepada nasabahnya, bank dituntut untuk mengembangkan strategi bisnis antara lain dengan memanfaatkan kemajuan teknologi. Pengembangan strategi tersebut selanjutnya mendorong investasi baru dalam teknologi yang digunakan dalam transaksi dan informasi.

Kehandalan bank dalam mengelola teknologi menentukan keberhasilan bank dalam 
menghasilkan suatu informasi yang lengkap, akurat, terkini, terpercaya, utuh, aman, konsisten, tepat waktu dan relevan sehingga informasi yang dihasilkan mendukungproses pengambilan keputusan dan operasional bisnis bank.

Sebagaimana firman Allah SWT dalam surah Al-Baqarah ayat 282 sebagai berikut:

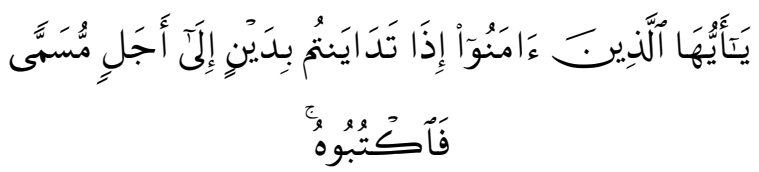

Artinya: Hai orang-orang yang beriman, apabila kamu bermuamalah tidak secara tunai untuk waktu yang ditentukan, maka tuliskanlah.(Al-quran dan terjemahnya, 2014:48)

Perintah ayat ini secara redaksional ditujukan kepada orang-orang beriman, tetapi yang dimaksud adalah mereka yang melakukan transaksi. Menurut Quraisy Shihab penggalan ayat ini meletakkan tanggung jawab di atas pundak penulis yang mampu bahkan setiap orang yang memiliki kemampuan untuk melaksanakan sesuatu sesuai dengan kemampuannya, menulis adalah perintah atau tuntunan yang sangat di anjurkan, perintah menulis dapat mencakup perintah kepada kedua orang bertransaksi.

Kata tadayantum, yang di atas diterjemahkan dengan bermuamalah. Kata ini memiliki banyak arti selalu menggambarkan hubungan antara dua pihak, salah satunya berkedudukan lebih tinggi dari pihak yang lain.(M. Quraisy Shihab, 2000:563-564)
E-muamalat menawarkan kemudahan dan kecepatan dalam melakukan transaksi perbankan. Dengan demikian, perbankan juga ikut memperlancar transaksi perdagangan dan peredaran uang dengan memberikan jaminan kepada nasabah, bertindak sebagai agen, serta memeberikan beberapa layanan lain termasuk yang berbasis teknologiinformasi seperti emuamalat. Adapun jasa perbankan yang dapat digunakan dengan dengan teknologi emuamalat antara lain adalah sebagai berikut:

1. Jasa Pengiriman Uang (Transfer)

Transfer secara umum adalah pengiriman uang lewat bank. Transfer dapat pula di artikan pemindahan uang dari rekening yang satu ke rekening yang lain dengan berbagai tujuan, baik dalam kota, luar kota, atau bahkan ke luar negeri

Pemilihan sarana yang digunakan dalam jasa transfer ini tergantung kemauan nasabah apakah lewat telex, telepon, atau on line komputer. Sarana yang dipilh akan mempengaruhi kecepata pengiriman dan besar kecil biaya pengiriman.

Keuntungan yang diperoleh bank dan nasabah lewat pengiriman uang atau transfer lewat bank adalah sebagai berikut:
a. Pengiriman uang lebih cepat
b. Aman sampai tujuan
c. Pengiriman dapat dilakukan lewat telepon melalui pembebanan rekening 
d. Prosedur mudah, murah, dan aman.(Ismail, 2010:153-158)

2. Jasa kartu kredit (Bank kedit)

Bank card merupakan "uang plastik" yang dikeluarkan oleh bank. kegunanaannya adalah sebagai alat pembayaran di tempat- tempat tertentu seperti supermarket, pasar swalayan, hotel, restorandan tempat lainnya. Di samping itu dengan kartu ini juga dapat di luangkan berbagai tempat seperti di ATM (automataed Teller Machine). ATM dewasa ini kita kenal dengan istilah Anjungan Tunai Mandiri yang biasanya tersebar di berbagai tempat berbagai strategis seperti di pusat perbelanjaan, hiburan, dan perkantoran.(Kasmir, 2014:139)

Beberapa jenis transaksi yang dapat dilakukan dengan menggunakan ATM antara lain:

a. Penarikan Tunai

b. Transfer antar rekening dalam bank yang sama atau bank yang berbeda

c. Pembayaran tagihan (rekening listrik, telepon, pembelian pulsa HP dan pembayaran tagihan kartu kredit

d. Pengoperasiannya mudah

e. Melayani 24 jam termasuk hari libur

f. Menjamin keamanan dan privacy.

3. Jasa pembayaran

Jasa ini diutamakan untuk membantu nasabahnya dalam mengumpulkan setoran atau pembayaran lewat bank. Setoran atau
POINT Vol. 2, No. 2, Des 2021 pembayaran yang biasa diterima oleh bank antara lain:
a. Pembayaran listrik
b. Pembayaran telepon
c. Pembayaran pajak
d. Pembayaran uang kuliah
e. Pembayaran lain-lain.

Jasa ini bertujuan untuk memudahkan nasabah dalam membayar kewajibannya cukup hanya ditempat.Dalam hal ini bank dapat pula memberikan pelayanan beruapa jasa pembelian seperti antara lain:
a. Pulsa telepon berbagai operator
b. Token PLN
c. TV berlangganan
d. Dan lain-lain.(Kasmir, 2006:119-120)

3. Pengertian Electronic Banking

Perkembangan pesat teknologi informasi dan globalisasi mendukung bank untuk meningkatkan pelayanan kepada nasabah secara aman, nyaman dan fektif diantaranya melalui media elektronic. Melalui e-banking, nasabah bank dapat pada umumnya dapat mengakses produk dan jasa perbankan dengan menggunkan peralatan electronik. Dalam pedoman ini yang dimaksud dengan Electonic Banking adalah layanan yang memungkinkan nasabah bank untuk memperoleh informasi, melakukan transaksi perbankan memalui media electronik.(Veithzal Rivai dan Rifki Ismail, 2013:361)

Sejarah Electronik Banking

Electronic Banking memliki sejarah panjang di Indonesia masuknya internet ke 
Indonedia dimulai dengan dibukanya layanan Interner Servise Provider (ISP) pertama yang didirikan oleh PT Indo Internet pada tahun 1994. Mulai tahun itu epidemi internet mampu menularkan 1,9\% dari 231 juta jiwa di Indonesia menjadi pengguna baru, atau sekitar 4,38 juta pengguna.(Suntoro, 2019:2)

Jenis transaksi Electronik Muamalat

Saat ini transaksi e-muamalat dapat melakukan banyak hal tetapi masih akan berkembang lebih jauh akan mendatang . Transaksi yang yang saat ini dapat dilakukan antara lain:

1. Transfer dana atau pemindahan dana Dua rekening di bank yang sama

a. Rekening di bank yang berbeda, misal rekening di bank $A$ ke rekening di bank B

b. Dan lain-lain

2. Informasi
a. Saldo
b. Transaksi
c. Dan lain-lain

3. Pembayaran
a. Listrik
b. Iuran TV Kabel
c. Kartu Kredit
d. Dan lain-lain.

Produk-produk electronik Muamalat

Ternyata e-muamalat tersebut telah melahirkan beberapa produk yang melalui jaringan yaitu:

1. Internet Banking
Internet Banking termasuk saluran yang memungkinkan nasabah melakukan transaksi via internet dengan menggunakan komputer/PC atau PDA. Fitur transaksi yang dapat dilakukan sama dengan phone banking yaitu informasi jasa/produk bank, informasi saldo rekening dan lain-lain.(Elisabeth, 2020:131)

2. Mobile Banking

Mobile Banking adalah layanan perbankan yang dapat diakses langsung melalui jaringan telepon seluler/hanphone dimana layanan data yang disediakan oleh operator telepon seluler.

3. Phone Banking

Phone Banking ini adalah saluran yang memungkinkan nasabah untuk melakukan transaksi dengan bank via telepon. Pada awalnya lazim diakses memalui telepon rumah.(Thomas, 2008:78)

4. SMS Banking

SMS Banking saluran ini pada dasarnya evolusi lebih lanjut dariphone banking, yang memungkinkan nasabah untuk bertransaksi via HP dengan perintah sms.

5. ATM

ATM atau anjungan tunai mandiri adalah saluran paling populer yang kita kenal, setiap kita pasti mempunyai kartu ATM dan menggunakannya untuk menegetahui informasi saldo dan melakukan penarikan.

Keunggulan dan kelemahan e-Muamalat

1. Keunggulan e-muamalat 
a. Dapat bertransaksi kapan saja dan dimana saja.

Sangat efisiensi, hanya dengan menggunakan komputer atau komputer, nasabah dapat langsung transaksi perbankan tanpa harus datang ke kantor bank. Efisiensi waktu dan efisiensi biaya.

2. Kelemahan e-muamalat

Resiko yang banyak terjadi adanya orang sekelompok orang yang dengan sengaja melakukan kegiatan phising. Artinya mereka membuat situs yang mirip dengsn situs bank aslinya, seningga tanpa disadari nasabah bahwa yang bersangkuta sedang mengakses situs palsu karena logo bank dan formatnya sama persis menyerupai aslinya.

\section{METODE}

Penelitian ini dilakukan di PT. Bank Muamalat Indonesia KCP Panyabungan berada di Jalan Williem Iskandar, Siobon Jae Kabupaten Mandailing Natal Provinsi Sumatera Utara. Waktu penelitian ini dimulai bulan Oktober 2020 sampai Juni 2021.

Jenis penelitian yang digunakan adalah jenis penelitian lapangan (field risearch). Dimana hasil penelitian berdasarkan hasil dari lapangan. (Lexy J. Moleong, 2012:49) Penelitian lapangan pada hakikatnya merupakan metode untuk menemukan secara khusus dan realistik apa yang tengah terjadi pada suatu saat ditengah masyarakat. Penelitian ini bertujuan untuk memecahkan masalah-masalah praktis dalam kehidupan sehari-hari. (Aji Damanuri, 2010:6)

Pendekatan penelitian yang digunakan adalah kualitatif dengan metode deskriptif. Penelitian kualitatif adalah suatu penelitian yang hanya menggambarkan keadaan dari objek yang akan diteliti sehubungan permasalahan objek yang akan dibahas.

Pendekatan penelitian yang digunakan adalah kualitatif dengan metode deskriptif. Penelitian kualitatif adalah suatu penelitian yang hanya menggambarkan keadaan dari objek yang akan diteliti sehubungan permasalahan objek yang akan dibahas.

Adapun metode deskriptif adalah penelitian yang mempelajari masalah-masalah dalam masyarakat, serta tata cara yang berlaku di masyarakat serta situasi-situasi termasuk tentang hubungan-hubungan, sikap-sikap, pandangan-pandangan, serta proses-proses yang sedang berlangsung dan pengaruhpengaruh suatu fenomena.

Menurut Burhan Bungin, subjek penelitian yaitu "Subjek penelitian adalah subjek yang dituju untuk diteliti oleh peneliti. Jika kita bicara dengan subjek, sebetulnya kita berbicara tentang unit analisis, yaitu subjek yang menjadi pusat perhatian atau sasaran peneliti.

Adapun subjek penelitian yang digunakan oleh peneliti dalam penelitian ini adalah bagian Relationship Manager (RM) 
Funding dan juga nasabah pada PT. Bank Muamalat Indonesia Tbk. KCP Panyabungan.

Adapun sumber data yang digunakan oleh peneliti adalah data-data dan dokumendokumen yang terkait dengan penelitian ini. Sumber data ini peneliti memperoleh dari:

1. Data Primer

Data primer merupakan sumber data yang langsung memberikan data kepada pengumpul data, data ini juga merupakan data yang didapat dari sumber pertama. Dalam penelitian ini penulis memperoleh data langsung dari PT Bank Muamalat Indonesia Tbk. KCP Panyabungan dengan wawancara secara langsung kepada pihak Bank dan nasabah

2. Data Sekunder

Data sekunder adalah sumber yang tidak langsung memberikan data kepada pengumpul data atau data yang diperoleh oleh pihak lain, yang diolah lebih lanjut dan disajikan oleh pihak lain, yang digunakan oleh penulis untuk memberikan gambaran seperti buku, jurnal, dan artikel yang berkaitan dengan penelitian ini.

Teknik pengumpulan data pada penelitian ini yaitu:

1. Observasi

Observasi atau pengamatan adalah kegiatan keseharian manusia dengan menngunakan panca indra mata sebagai alat bantunya selain panca indra lainnya seperti telinga, penciuman, mulut, dan kulit. Oleh karena itu observasi adalah kemampuan seseorang untuk menngunakan pengamatannya melalui hasil kerja panca indra lainnya. Metode observasi adalah pengumpulan yang digunakan untuk menghimpun data penelitian, data-data tersebut dapat diamati oleh peneliti.

2. Wawancara

Wawancara merupakan pengumpulan data dengan cara tanya jawab antara informasi dengan peneliti. Menurut Bogdan dan Biklen wawancara adalah percakapan yang bertujuan, biasanya antara dua orang (tetapi kadang-kadang lebih) yang diarahkan oleh salah seorang dengan maksud memperoleh keterangan.

Menurut Burhan Bungin, wawancara adalah proses percakapan dengan maksud untuk mengintruksi mengenai orang, kejadian, kegiatan, organisasi, motivasi, perasaan dan sebagainya yang dilakukan dua pihak yaitu pewawancara (intervienwer) yang mengajukan pertanyaan dengan orang yang diwawancarai (interviewe). Dalam wawancara ini peneliti mengadakan tanya jawab dengan staff/karyawan Bank Muamalat Indonesia KCP Panyabungan dan nasabah.

3. Dokumentasi

Dokumentasi yaitu metode yang dipakai dengan mencari data mengenai hal-hal yang berupa catatan wawancara, foto wawancara, surat kabar, dan lain-lain 
Misbah ${ }^{1}$, Budi Gautama Siregar ${ }^{2}$, Muhammad Wandisyah $\mathbf{R}^{3}$, Samsuddin Muhammad

yang berisikan informasi mengenai Bank

Muamalat Indonesia.

Penelitian ini dilakukan dalam bentuk analisis kualitatif dengan metode deskriptif.Apabila ditinjau dari proses sifat dan analisis datanya maka dapat digolongkan kepada research deskriptif yang bersifat eksploratif yaitu penelitian deskriptif yang sifatnya menggambarkan lewat analisis dalam penelitian ini bertujuan untuk mendeskripsikan tentang penggunaan fasilitas e-muamalat dalam menarik minat nasabah pada PT. Bank Muamalat Indonesia Tbk. KCP Panyabungan. Setelah data terkumpul, maka dilakukan analisis data dengan metode kualitatif deskriptif. Analisis secara kualitatif dilakukan dengan langkah-langkah sebagai berikut:

1. Klasifikasi data adalah menyeleksi data dan mengelompokkan sesuai dengan topiktopik pembahasan.

2. Reduksi data adalah memeriksa kelengkapan data untuk mencari data yang masih kurang dan mengesampingkan yang tidak relevan.

3. Editing data adalah menyusun redaksi data menjadi susunan kalimat sistematis.

4. Deskripsi data adalah menguraikan data secara sistematis, induktif dan deduktif sesuai dengan sistematis pembahasan.

5. Penarikan kesimpulan adalah menerangkan uraian-uraian penjelasan ke dalam susunan yang singkat dan padat.
POINT Vol. 2, No. 2, Des 2021

Adapun hal-hal yang harus dilakukan peneliti untuk mendapatkan data yang akurat adalah sebagai berikut:

1. Perpanjang Keikutsertaan

Keikutsertaan adalah peneliti sangat menentukan dalam pengumpulan data. Keikutsertaan tersebut tidak hanya dilakukan dalam waktu singkat, tetapi memerlukan perpanjangn keikursertaan peneliti pada latar penelitian. Perpanjangan keikutsertaan peneliti akan memumgkinkan peningkatan derajat kepercayaan data yang dikumpulkan.

2. Ketekunan Pengamatan

Ketekunan pengamatan dalam penelitian ini bermaksud menemukan ciri-ciri unsur dalam situasi yang sangat relevan dengan persoalan atau isu yang sedang dicari dan kemudian memusatkan diri pada hal-hal tersebut secara rinci. Dengan kata lain, jika perpanjangan keikutsertaan menyediakan lingkup maka ketekunan pengamatan menyediakan kedalaman.

3. Tringulasi

Menurut Laxy J. Moleong, tringulasi merupakan teknik pemeriksaan keabsahan data yang memanfaatkan sesuatu diluar data itu untuk keperluan pengecekan atau sebagai pembanding terhadap data itu.

\section{HASIL DAN PEMBAHASAN}

1. Persepsi Nasabah Terhadap Produk EMuamalat Pada PT. Bank Muamalat Indonesia Tbk. KCP. Panyabungan 
Persepsi adalah proses pemberian makna pada sensasi sehigga manusia memperoleh pengetahuan yang baru. Istilah persepsi biasanya digunakan untuk mengungkapkan tentang pengalaman terhadap suatu benda atau suatu kejadian yang dialami. Pada hakikatnya persepsi adalah suatu proses aktifitas seseorang dalam memberikan kesan, penilaian, pendapat, merasakan dan menginterpretasikan sesuatu berdasarkan informasi yang dipersepsi. Sehingga dapat menerima dan menyadap informasi dari lingkungan sekitar.

Dalam proses persepsi individu dituntut untuk memberikan penilaian terhadap suatu objek yang dapat bersifat positif dan negatif, senang atau tidak senang dan sebagainya. Dengan adanya persepsi maka akan terbentuk sikap, yaitu suatu kecenderungan yang stabil untuk berlaku atau bertindak di dalam situasi yang tertentu.

Seperti yang dikatakan ibu Patimah Nasution, Produk E-Muamalat sangat membantu beliau, karena dengan super cepat dan akurat. Beliau tidak perlu datang lagi ke kantor Bank Muamalat Indonesia KCP Panyabungan dengan proses transfer uang sekolah anak beliau, selain itu penggunaannya yang sangat aman dan ibu tersebut mengetahui produk E-Muamalat dari salah satu pegawai Bank Muamalat Indonesia Tbk. KCP Panyabungan.
Selain itu, dengan bapak Lahmuddin Lubis dimana pendapat beliau berbanding terbalik, beliau sudah mengetahui produk E-Muamalat namun beliau tidak menggunakannya, karena minimnya pengetahuan dalam menggunakannya dan tidak terlalu memahami tentang cara-cara dalam penggunaan apalagi berbasis Smarphone atau aplikasi dan lebih memilih bertransaksi datang ke ke kantor.

Sedangkan Bapak Muhammad Lukmanmengatakan bahwa dengan menggunakan produk E-Muamalat sangat membantu beliau dalam proses transaksi, kareana selain cepat biaya administrasi yangamat murah dan beliau sudah lama menggunakannya karena tidak ada biaya administrasi bulanan.

Selain itu Ibu Melda Hayani, mengatakan bahwa menggunakan EMuamalat sangat mudah dan cepat, akan tetapi sangat di sayangkan beliau tidak menggunakannya karena jaringan di Desa yang kurang mendukung sehingga beliau harus datang ke kantor untuk bertransaksi di Bank Muamalat Indonesia KCP Panyabungan.

Sedangkan dengan lbu Rosmayana Harahap mengatakan penggunaan EMuamalat yang sangat mudah dan cepat.Mengunakan

E-Muamalat memehuhi sesuai kebutuhannya.karena gak harus datang lagi ke penagihan listrik atau penagihan lainnya. 
Misbah ${ }^{1}$, Budi Gautama Siregar ${ }^{2}$, Muhammad Wandisyah $R^{3}$, Samsuddin Muhammad ${ }^{4}$

Selain itu dengan Ibu Novita Sari Batubara mengatakan dengan menggunakan E-Muamalat yang super cepat dan akurat. Apabila ingin bertransaksi gak harus datang lagi ke kantor Bank.

Sedangkan dengan Bapak Suheri beliau mengatakan dengan menggunakan E- Muamalat, pekerjaan jadi gak terganggu. Cukup menggunakan Smartphone bisa langsung bertransaksi.

Sedangkan dengan Ibu Khoirunnisah mengatakan dengan menggunakan EMuamalat sangat membantu beliau karena proses transaksi yang super mudah dan cepat.

Selain dengan Ibu Hanifah beliau mengatakan menggunakan E-Muamalat sangat bermanfaat karena proses bayar tagihan jadi cepat seperti tagihan token listrik.

Sedangkan dengan Ibu Putri Ayu mengatakan dengan mengunakan EMuamalat beliau gak perlu harus datang lagi ke kantor untuk bertransaksi apalagi lokasi rumah beliau dengan kantor lumayan jauh dengan E-Muamalat kebutuhan terpehuhi dengan cepat.

Dari hasil wawancara yang diperoleh alasan nasabah terhadap penggunaan EMuamalat, peneliti memperoleh hasil informasi mengenai penggunaan $\mathrm{E}$ Muamalat yang super cepat dan akurat, dan untuk lebih meningkatkan minat
POINT Vol. 2, No. 2, Des 2021 nasabah menggunakan yaitu promosi dimana promosi merupakan sarana yang paling ampuh untuk menarik minat dan mempertahankan nasabahnya salah satu tujuan promosi adalah menginformasikan segala jenis produk yang ditawarkan dan mejelakan dengan rinci atas produknya.

2. Faktor-Faktor yang Menyebabkan nasabah menggunakan E-Muamalat Pada PT. Bank Muamalat Indonesia KCP Panyabungan.

Pada dasarnya faktor-faktor yang mempengaruhi terbagi menjadi dua yaitu faktor internal dan eksternal.

a. Faktor Internal

Faktor internal adalah faktor yang terdapat dalam diri individu yang mencakup beberapa hal sebagai berikut

1) Fisikologis.

Informasi yang masuk melalui alat indera, selanjutnya informasi yang diperoleh akan mempengaruhi serta melengkapi usaha untuk memberikan arti pada lingkungan sekitarnya. Setiap orang memiliki keinginan yang berbeda-beda bergantung kapasitas indera individu sehingga sehingga interpretasi lingkungan juga dapat berbeda.

2) Perhatian.

Individu memerlukan sejumlah energi yang dikeluarkan untuk memperhatikan dan memfokuskan pada bentuk fisik dan fasilitas yang ada pada suatu objek. 
Dapat dilihat kuatnya individu mencari objek-objek atau pesan sehingga dapat memberikan jawaban yang sesuai dengan individu.

\section{b. Faktor Eksternal}

Faktor eksternal dipengaruhi dari lingkungan dan objek- objek yang terlibat di dalamnya. Yang dapat mengubah sudut pandang individu terhadap lingkungan sekitarnya.Tidak hanya itu saja dapat mempengaruhi bagaimana individu dapat merasakan atau menerimanya.

Seperti yang dikatakan Ibu Patimah Nasution, dimana beliau tidak mau ketinggalan akan suatiu produk terbaru dari E-Muamalat, apalagi di daerah lingkungan nya rata-rata sudah menggunakannya.

Dapat dilihat dari penejelasan di atas, bahwa unsur-unsur yang meneyebabkan faktor mnggunakan terhadap E-Muamalat salah satu dari lingkungannya. Dimana semakin berkembangnya teknologi informasi di jaman modern ini sehingga tidak mau ketinggalan akan sesuatu hal yang baru, dan memanfaatkankan sesuai dengan kebutuhannya.

Dapat dilihat dari penjelasan di atas bahwa unsur-unsur persepsi terbentuk karena adanya faktor dalam lingkungan serta lingkungan luar. Dari beberapa faktor tersebut terbentuklah beberapa macam persepsi yang setiap orang memiliki persepsi yang berbedabeda yang timbul akibat keadaan sekitar dalam meminati sesuatu hal.
Analisis Penelitian

Nasabah merupakan nafas kehidupan bagi bank agar mampu menjalankan setiap kegiatannya. Setiap bank dituntut untuk memberikan pelayanan yang baik dan berkualitas. Dengan berbagai layanan menarik dari berbagai bank, maka masyarakat akan lebih selektif dalam memilih lembaga keuangan yang menurut mereka adalah adalah terbaik, peran karyawan atau seseorang pelayan dalam dunia perbankan sangat pentings eiring dengan meningkatnya pesaing bisnis di dunia perbankan.

Perbankan menyadari betapa pentingnya memperoleh dan mempertahankan kepercayaan nasabah bagi keberhasilan bisnis bank. Perbankan berlomba-lomba menunjukkan sikap lebih menghargai nasabah dan mengembangkan fasilitas yang ada dengan memberikan pelayanan yang terbaik, maka pastinya akan lebih banyak masyarakat yang berminat menggunakan jasa perbankan.

Layanan yang diberikan bank mempunyai nilai bagi nasabah jika dilihat dari banyak manfaat yang di berikan bank untuk memenuhi kebutuhan yang diminta para nasabah. Manfaat yang dimaksud ketika suatu sistem yang disediakan banyak digunakan dan dapat di pahami secara mudah atas produk yang ditawarkan. Misal pada fitur yang disediakan ebanking pada aplikasi yang akan dibuka maka tidak semua nasabah mengerti atau mau menggunakan layanan yang disediakan. 


\section{Berdasarkan hasil penelitian dan} wawancara yang peneliti laksanakan pada PT. Bank Muamalat Indonesia Tbk. KCP Panyabungan, bertambahnya minat masyarakat terhadap E-Muamalat dapat dipengaruhi oleh beberapa faktor, antara lain: berbagai fasilitas yang ditawarkan oleh Bank Muamalat Indonesia Tbk. KCP Panyabungan. Minat adalah sesutatu kecenderungan yang tetap untuk diperhatikan dalam kegiatan, jika kegiatan yang diminati seseorang itu diperhatikan terus-menerus dengan disertai rasa senang, makaia dapat mengembangkan minat pada sesuatu kegiatannya. Faktor yang mempengaruhi ketertarikan akan minat nasabah untuk menggunakan E-Muamalat pada Bank Muamalat Indonesia Tbk. KCP Panyabungan yaitu dari segi produknya, dimana produk EMuamalat sesuai dengan kebutuhan.

Selain itu dari segi pelayanan Bank Muamalat Indonesia Tbk. KCP Panyabungan memiliki pelayanan yang sopan santun dan jugak bertanggung jawab. Kemudian dimana dalam penggunaan atau proses mudah dan cepat, selain itu dengan adanya lokasi kantor yang fasilitasnya yang strategis dengan sarana yang memadai dan peralatan kantor yang lengkapserta karyawan yang bernampilan rapi.

Persepsi masyarakat adalah sebagai proses yang dilakukan individu untuk memilih, mengatur dan menafsirkan ke dalam gambaran yang berarti dan masuk akal, persepsi ini merupakan suatu proses yang timbul akibat adanya sensasi. Sensasi merupakan dimana kita POINT Vol. 2, No. 2, Des 2021
membuat kita terasa menggembirakan ataupun sebaliknya. persepsi nasabah menggunakan E-Muamalat yang super cepat dan akurat. Produk E-Muamalat sesuai dengan kebutuhan nasabah,mengingat akan kebutuhan masa depan.

Adapun faktor-faktor yang menyebabkan nasabah menggunakan E-muamalat yaitu faktor internal dan eksternal, Faktor dalam lingkungan serta lingkungan luar. Dimana lingkungan mempengaruhi individu untuk merasakan atau menerima, dimana semakin berkembangnya di jaman modern ini sehingga invidu tertarik untuk menggunakannya.

\section{E. Kesimpulan dan Saran}

\section{Kesimpulan}

Berdasarkan analaisis yang telah dilakukan oleh penulis mengenai Penggunaan Fasilitas E-Muamalat untuk menarik minat nasabah pada PT. Bank Muamalat Indonesia Tbk. KCP Panyabungan, maka dapat diambil kesimpulan:

1. Persepsi nasabah terhadap produk EMuamalat pada PT. Bank Muamalat Indonesia Tbk. KCP Panyabungan dimana dalam penggunaannya sangat praktis yang super cepat dan akurat, tanpa harus datang langsung ke Bank untuk bertransaksi. Selain itu E-Muamalat terjamin akan kemananannya.

2. Faktor yang menyebabkan nasabah menggunakan E-Muamalat pada PT. Bank Muamalat Indonesia Tbk. KCP Panyabungan dimana semakin 
berkembangnya terknologi informasi di zaman modren ini sehingga tidak mau ketinggalan akan sesuatu hal yang baru, dan memanfaatkannya

\section{Saran}

Semoga adanya pengetahuan masyarakat maka adanya penambahan terhadap jumlah nasabah perbankan syariah.

\section{DAFTAR PUSTAKA}

Aji Damanuri. 2010. Metodologi Penelitian Muamalah. Ponorogo: STAIN Ponorogo Press.

Al-quran dan terjemahnya. 2014. Al-Qur'an surah Al-Baqarah ayat 282. Surabaya.

Bustari dan kurnia. 2016. Bank dan Keuangan Lain. Jakarta: Kencana.

Damri Batubara, dkk. 2020. "Pengaruh Persepsi terhadap Minat Memilih Baitul Maal Wat Tamwil (BMT) Insani Padangsidimpuan." JISFIM: Journal of Islamic Social Finance Management Volume 1 Nomor 1 (Juni): hlm. 46.

Edhy Sutanta. 2017. Sistem Informasi Manajemen. Yogyakarta: Graha IImu.

Elisabeth. 2020. Sistem Berbasis Teknologi di Era Digital. Jakarta: kita menulis.

Ikatan Bankir Indonesia. 2014. Mengelola Kualitas Layanan Perbankan. Jakarta: Gramedia Pustaka.
Ismail. 2010. Manajemen Perbankan dari teori Menuju Aplikasi. Jakarta: Prenamedia Group.

- - . 2011. Perbankan Syariah. Jakarta: Prenada Media.

Kasmir. 2006. Manajemen Perbankan. Jakarta: Raja Prafindo Persada.

- - . 2014. Manajemen Perbankan. Jakarta: Grafindo Persada.

Lexy J. Moleong. 2012. Metodologi Penelitian Kualitatif. Bandung: Remaja Rosda Karya.

M. Quraisy Shihab. 2000. Tafsir Al-Mishbah. Ciputat: Lentera Hati.

Maryanto Supriyono. 2011. Buku Pintar Perbankan. Yogyakarta: Andi.

Muhibbin Syah. 2003. Psikolog Belajar. Jakarta: Raja Grafindo Persada.

Nasrul Makdis. 2020. Pemanfaatan Internet Untuk Perkuliahan. Jawa tengah: Penapersada.

Sarjono Soekanto. 2002. Pengantar Sosiologi. Jakarta: Gema Insani.

Suntoro. 2019. Fundamental Manajemen Logistik. Jakarta: Kencana.

Thomas. hlm. 78. Ilmu Sosial Gramedia. Jakarta: 2008.

Veithzal Rivai dan Rifki Ismail. 2013. Islamic Risk Management For Islamic Bank. Jakarta: Gramedia Pustaka Utama. 